\title{
INDUSTRIAL RESTRUCTURING AND DOWNSIZING: CASE STUDY OF CENTRAL CROATIA
}

Jelena Lončar, Zdenko Braičić

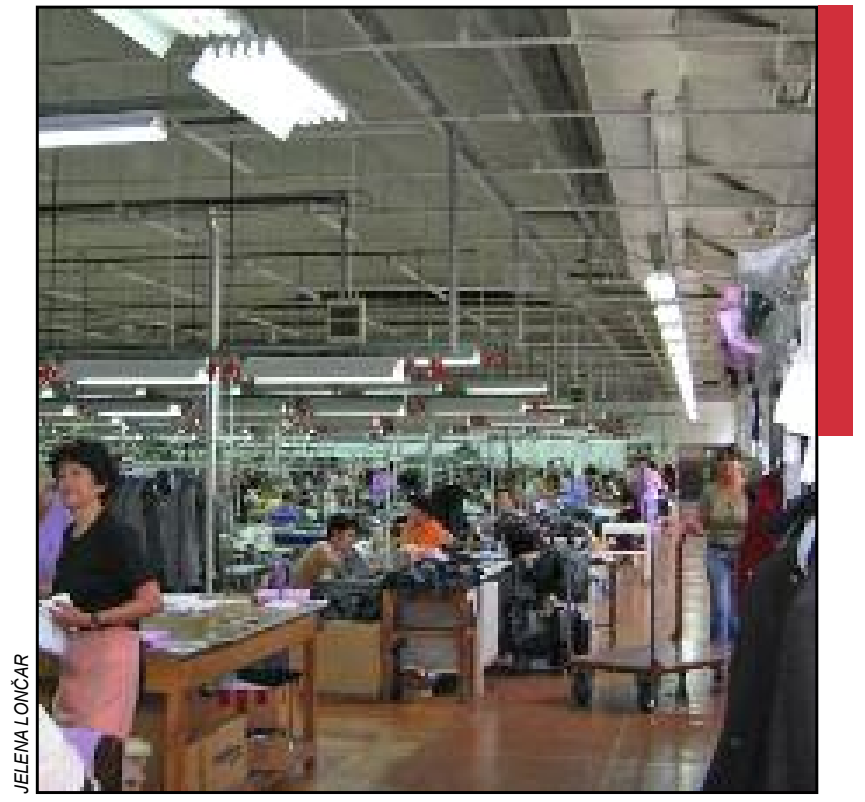

Textile firm Kratex, from Krapina. 


\title{
Industrial restructuring and downsizing: Case study of Central Croatia
}

DOI: http://dx.doi.org/10.3986/AGS.1886

UDC: $911.3: 330.341 .424(497.52)$

COBISS: 1.01

\begin{abstract}
The collapse of socialist economic system in Croatia was followed by a period of economic transition during which the industry sector was affected by major changes. This study, on an example of Central Croatia, analyzes the spatial aspect of these changes between 1990 and 2011 . The used data were taken from the National Bureau of Statistics and studies in which the transition period industry is researched from economic and geographical point of view. Calculations of most indicators referred to a county level while some indicators were calculated at the level of administrative cities and municipalities. It was found that, in Central Croatia, there had come to a process of deindustrialization, and in some rare cases a process of reindustrialization, an increase in importance of tertiary and quaternary activities, and calculation of some indicators such as degree of industrialization, location quotient, regional factor and index of specialization indicated on the existence of significant differences between individual parts of Central Croatia.
\end{abstract}

KEY WORDS: geography, industry, transition, deindustrialization, reindustrialization, Croatia

The article was submitted for publication on December $16^{\text {th }}, 2013$.

\section{ADDRESSES:}

Jelena Lončar, Ph.D.

University of Zagreb, Science Faculty, Department of Geography

Marulićev trg 19, 10000 Zagreb, Croatia

E-mail: jloncar@geog.pmf.hr

Zdenko Braičić, Ph.D.

University of Zagreb, Education Faculty

Savska 77, 10000 Zagreb, Croatia

E-mail: zdenko.braicic@sk.t-com.hr 


\section{Introduction}

Industry is an economic activity that has in Croatia, over the past twenty years, gone through fundamental changes. In 2011 secondary sector (mining, industry, construction, production crafts) participated in national income of Croatia with 34 per cent (Magaš 2013). But, during the transition of the economy, industry had become virtually a marginalized activity with a significantly decreased share in Croatian GDP, decrease in a number of employees as well as a decrease in a number of industrial businesses. A little more than twenty years ago, Croatian industry employed more than 600.000 workers, while their number has been reduced to 206.823 workers by 2011. In other words, there had come to a deindustrialization process in Croatian economy followed by its tertiarization. However, in the Central Croatia area, industry still has a relatively high importance, as evidenced by data on 122.675 people employed in industry, which is more than a half of number of employees in the industry of whole Croatia. The aim of this study is to see to what extent have these changes reflected on the space of counties, municipalities and cities of Central Croatia. In doing so, the current state and the impact of recent financial (global) crisis shall not be analyzed in detail, since these issues should be processed in a separate research paper.

\section{Theoretical framework}

In this paper, the authors analyzed the changes that happened in industrial activity during the period from 1990 to 2011, and Central Croatia had been chosen as a case study because, when it comes to industry, it was and still is one of the most developed Croatian regions, particularly in its north-western parts. Also, the choice of this region was taken because of significant changes that have affected the selected activity in this area-from deindustrialization to restructuring, but also a complete collapse of certain industries. Unfortunately, as some data of Croatian population census from 2011 are not yet available, they could not be included into this analysis.

The purpose of this study is to determine the extent to which changes have affected industry in Central Croatia during the period of last twenty years, and according to this, two hypotheses were made: 1. Economic transition, as well as restructuring of the industry have led to even greater economic and development differences among individual parts of Central Croatia than it was before 1990, i.e. economic disparities among different regions (counties) which were equally economically developed before transition; 2 . The north-western part of Croatia has restructured industry better and has overcome transitional problems more successfully than southern and eastern parts of Central Croatia. Although some economy authors believe that transition ended in 2004, when GDP reached its pre-transitional level, other authors also consider that it is interesting to observe the period after 2004 due to unfinished privatization of some (big) companies in Croatia as well as transitional problems that still largely reflect on activities in industry as a whole.

\section{Research methodology}

This study is based on the analysis of several statistical models which were used, namely: models which analyze spatial distribution of certain phenomena (degree of industrialization, location quotients) and models that indicate specialization or diversification (index of specialization).

The degree of industrialization was calculated by the following formula:

$$
D_{\text {ind }}=A: B \pm 1000
$$

(where Dind is - degree of industrialization, A - number of employees in industry, a B - total population). Together with the degree of industrialization, another used indicator was location quotient. The location quotient is one of the scales for spatial distribution of industry, i.e. the degree of concentration of industry in a smaller compared to a larger spatial area. It was calculated according to:

$$
L Q=b_{2}: a_{2} / B_{1}: A_{1}
$$

where LQ is the location quotient, $b_{2}$ is a number of industrial workers in the smaller area (county), $a_{2}$ is a number of industrial workers in the larger area (Central and Croatia in general), B1 is a number of residents in the smaller area, and $\mathrm{B}_{2}$ is a number of residents in the larger area. The following term was used to calculate the index of specialization:

$$
\text { Ispec }=A_{1}: A_{2} / B_{1}: B_{2}
$$

where $A_{1}$ - a number of employees in the smaller area in a certain activity, $A_{2}$ - a total number of employees in the smaller area, $B_{1}-$ a number of employees in the larger area in a certain activity, $B_{2}-$ a total number of 
employees in the larger area. If the resulting index is greater than 1.00, then the particular area (county) is considered specialized in a certain area of economy, i.e. in the economic activity. All data and information were analyzed in detail and compared to each other in order to identify actual trends and bring appropriate conclusions.

When analyzing this problem, when it comes to geographers, a certain number of studies considering Croatia, were conducted by Feletar and Stiperski $(1992 ; 1997)$ and later Lončar and Braičić $(2011,2012)$ who analyzed problems especially of Sisak-Moslavina county.

\section{Analysis of changes in industrial activities in Central Croatia}

The transformation from a socialist country and country-planned economy towards a western-style democracy and market based economy has caused dramatic changes in economic, social, ecological and spatial development in post-socialist countries (Miljanović et al. 2010). Also, with the fall of the socialist system, new states were faced with challenges that were unpredictable in many aspects (Lorber 1999). One of the major challenges in these new terms was industry. Industry is still one of the main growth drivers in every economy. Industry in the EU is no longer based on labor-intensive activities, and the cost of these changes has affected employment, i.e. in increase of unemployment, while the low-skilled work force seems to be a permanent loser. This especially applies to textile and clothing industry (Teodorović and Buturac 2006). When it comes to industry, privatization was aimed at accelerating restructuring of industrial companies and profitable placement of product and services on competitive and international markets (Kalogjera 1993). This fact also refers to industrial companies that are particularly significant for the Central Croatia region which is the subject of this study.

The attractiveness of an area for development of industry is based on interdependence among various groups of economic, demographic and other factors and industrial development in municipalities and cities in Croatia (Stiperski 1995). The most important industrial areas are connected to leading urban centers and their urbanized regions. Several industrial areas can be highlighted in Central Croatia, primarily the wider area of Zagreb, Međimurje-upper Podravina area including Varaždin, Čakovec and Koprivnica (Magaš 1998). Industry in these areas employed 24.137 workers in 2011 , which is $20 \%$ of the total number of employees in industry of Central Croatia. This is also the largest industrial region in Croatia. Due to war and deindustrialization process, industrial production and the number of industrial companies in certain counties decreased significantly compared to pre-war period. The rapid process of deindustrialization reduced the degree of utilization of national resources, both natural and labor, which has lead to major regional differences in development. During this process, smaller counties and cities were visibly lagging behind (Lokin, Mlinarević and Živković 2007). This particularly applies to Sisak-Moslavina County in which the number of mentioned companies almost halved in 1996 compared to 1990 and which has never fully succeeded in bringing industry to its pre-war state. This is a consequence of direct and indirect damages caused by direct attacks on objects, inability to supply raw materials due to roads hindrance, decrease in realization because of economic blockade, inability to pay, during the Homeland war. It should be noted that analysis included all data on the number of industrial companies for the whole period 1990-2007 (the last year data is publicly available for), but because of the extent and large amount of data, this study includes data for only every five years starting from 1991.

Table 1: Number of industrial companies by counties of Central Croatia in five-year periods, 1990-2007.

\begin{tabular}{lrrrrr}
\hline County & 1991 & 1996 & 2001 & 2006 & 2007 \\
\hline Zagreb & 57 & 118 & 107 & 283 & 287 \\
Krapina-Zagorje & 67 & 69 & 62 & 133 & 141 \\
Sisak-Moslavina & 107 & 61 & 51 & 92 & 104 \\
Karlovac & 71 & 88 & 71 & 124 & 134 \\
Varaždin & 99 & 102 & 88 & 176 & 182 \\
Koprivnica-Križevci & 40 & 52 & 51 & 81 & 89 \\
Bjelovar-Bilogora & 67 & 76 & 71 & 101 & 110 \\
Međimurje & 51 & 70 & 75 & 163 & 174 \\
City of Zagreb & 303 & 358 & 376 & 770 & 792 \\
\hline Central Croatia & 862 & 1.033 & 952 & 1.923 & 2.013 \\
\hline
\end{tabular}

Source: Croatian Bureau of Statistic, 2002; 2007a; 2007b; 2008a; 2008b 
From data we can see that there are more industrial companies in north-western part of Central Croatia, including the Zagreb County, while their number is lower in eastern and southern regions. This leads to a conclusion that the north-western part of Central Croatia has been and still remains its industrial core. Industrial development has an important role in employment because it provides great opportunities for employing the work force, not only in industry, but in many other sectors, including services (Obadić 2004). In order to better understand changes that occurred during transition, it is necessary to analyze changes in the number and proportion of workers employed in industry by counties (Table 2).

Table 2: The number of employees in industry by counties of Central Croatia 1991-2011 and the per cent of industry employees in total number of employees

\begin{tabular}{lccccc}
\hline County & $1991^{*}$ & 1996 & 2001 & 2006 & 2011 \\
\hline Zagreb & 10.819 & 14.951 & 10.346 & 14.068 & 12.324 \\
$\%$ & - & 40,7 & 8,6 & 24,0 & 22,2 \\
\hline Krapina-Zagorje & 17.946 & 12.257 & 8.619 & 9.459 & 8.566 \\
$\%$ & - & 44,8 & 14,3 & 35,7 & 33,8 \\
\hline Sisak-Moslavina & 29.444 & 13.466 & 10.386 & 10.570 & 9.954 \\
$\%$ & - & 39,4 & 18,2 & 28,9 & 29,5 \\
\hline Karlovac & 19.862 & 11.480 & 8.055 & 8.868 & 6.998 \\
$\%$ & - & 41,3 & 16,9 & 29,3 & 24,8 \\
\hline Varaždin & 26.754 & 19.095 & 17.087 & 20.056 & 18.876 \\
$\%$ & - & 45,1 & 24,9 & 41,0 & 40,3 \\
\hline Koprivnica-Križevci & 15.650 & 13.067 & 11.697 & 11.662 & 8.539 \\
$\%$ & - & 48,2 & 24,3 & 43,6 & 35,7 \\
\hline Bjelovar-Bilogora & 12.734 & 8.552 & 6.415 & 7.496 & 6.798 \\
$\%$ & - & 34,1 & 11,9 & 30,0 & 29,7 \\
\hline Međimurje & 13.499 & 10.691 & 10.514 & 12.570 & 12.055 \\
$\%$ & - & 44,4 & 19,5 & 43,4 & 46,5 \\
\hline City of Zagreb & 104.777 & 66.287 & 80.716 & 78.945 & 38.565 \\
$\%$ & - & 30,2 & 27,2 & 23,2 & 11,7 \\
\hline Central Croatia & 251.485 & 169.846 & 163.835 & 173.694 & 122.675 \\
\% & - & 34,9 & 20,3 & 27,9 & 20,8 \\
\hline
\end{tabular}

*No data available. Counties as territorial units were formed in 1993 , so for all previous periods there is no data by certain activities on that level. Source: Croatian Bureau of Statistic, 1993; 1994b, 1996a; 1997; 2002; 2007a; 2007b; 2008b; 2012a

A partial recovery, as an increase in the number of industrial workers in most counties, started in 2002/2003 when Croatia began moving significantly towards the European Union (Stabilization and association agreement was signed in 2001 and put to force in 2005). In the following years, from 2004 to 2007, the number of industrial workers increased slightly in all counties. In the last observed period, until 2011, the number of industry workers decreased in all counties, especially in the City of Zagreb. That is an indication of Zagreb transforming from an industrial city into a city of tertiary and quaternary characteristics, as well as a further deindustrialization process. The number of employees in this county in secondary sector decreased by more than $50 \%$. At the level of Central Croatia, the number of employees in industry in the 2006-2011 period declined by more than 50.000 . When it comes to industrial productivity, in the first decade of $21^{\text {st }}$ century, it was two times higher than in the eighties. Low productivity during the eighties had become even lower in the nineties. The reason for this is a more rapid decrease in industrial production than in industrial employment. The lowest productivity was in 1991, when the index was $61(2000=100)$. In the eighties, productivity ranged from 71 to 76, but since 1991 it has grown continuously (Stiperski 2007).

\section{Spatial distribution of industry in Central Croatia}

In order to determine changes in the number of employees in industry, one of the simplest and most frequent quantitative models of industrial geography was used-the degree of industrialization. Depending on 


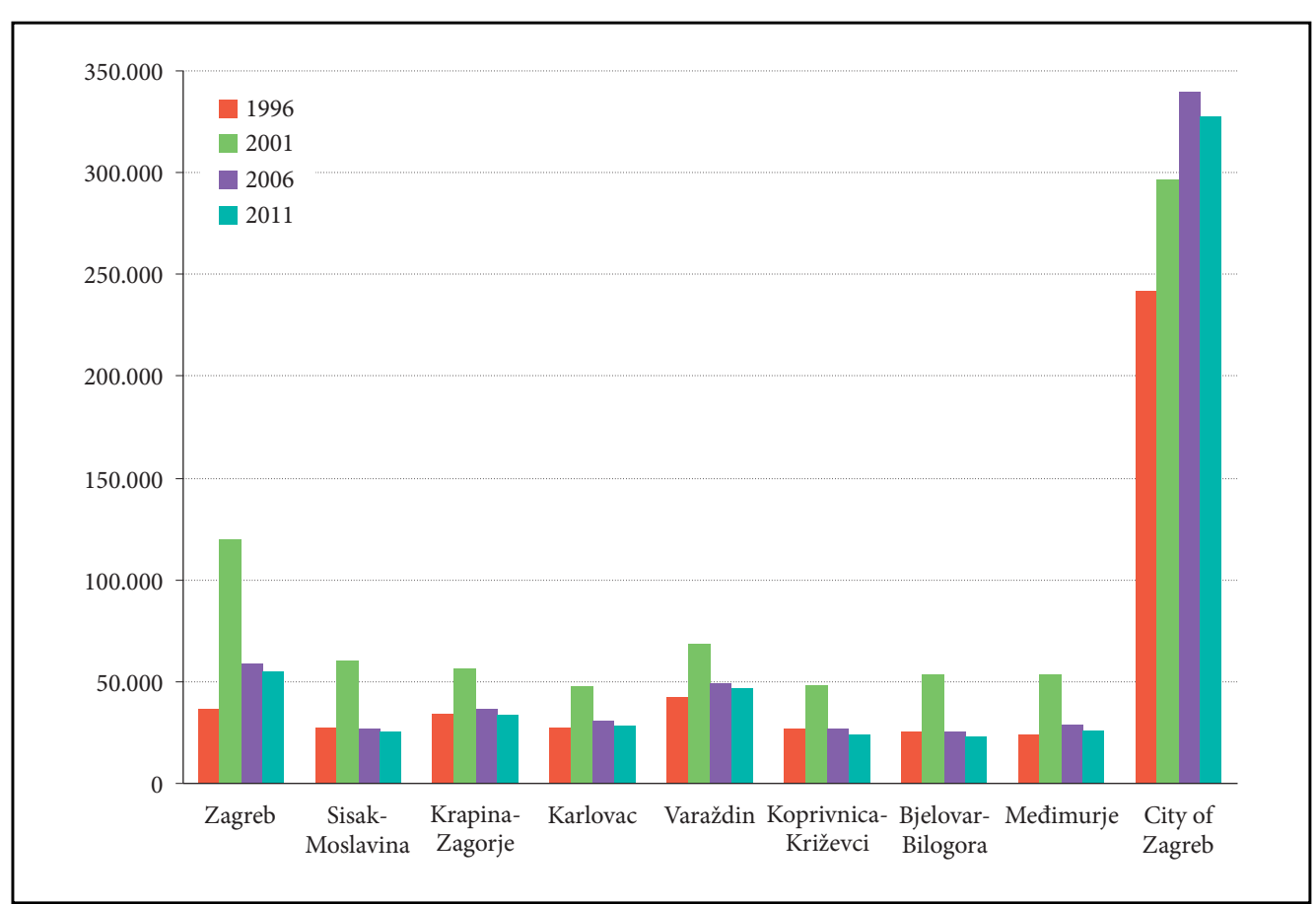

Figure 1: Total number of employees in all activities, by counties, 1996-2011 (Croatian Bureau of Statistics 1997a; 1997b; 2012a; 2012b)

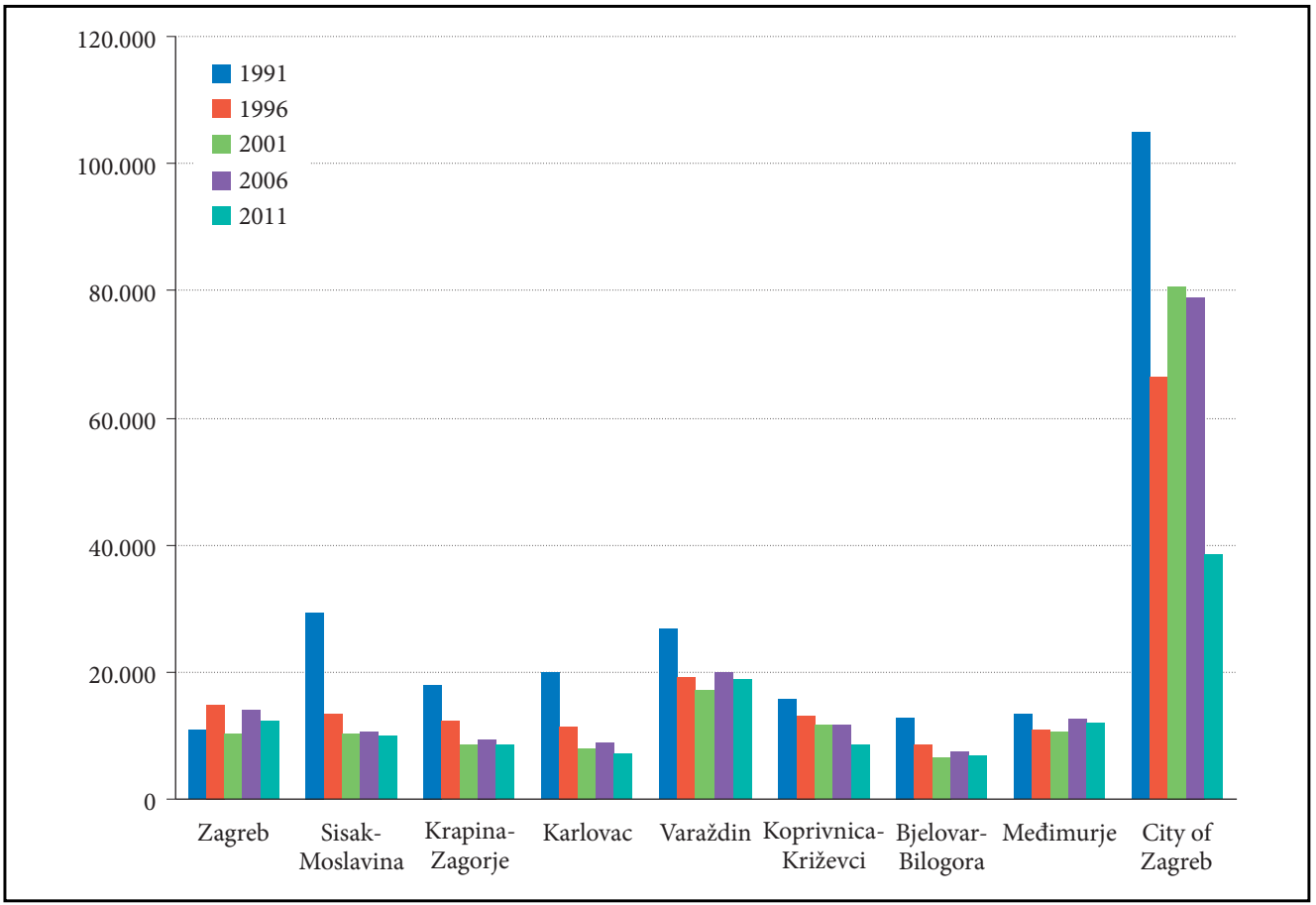

Figure 2: Employed in industry, by counties, 1991-2011 (Croatian Bureau of Statistics 1992a; 1992b; 2012a; 2012b) 


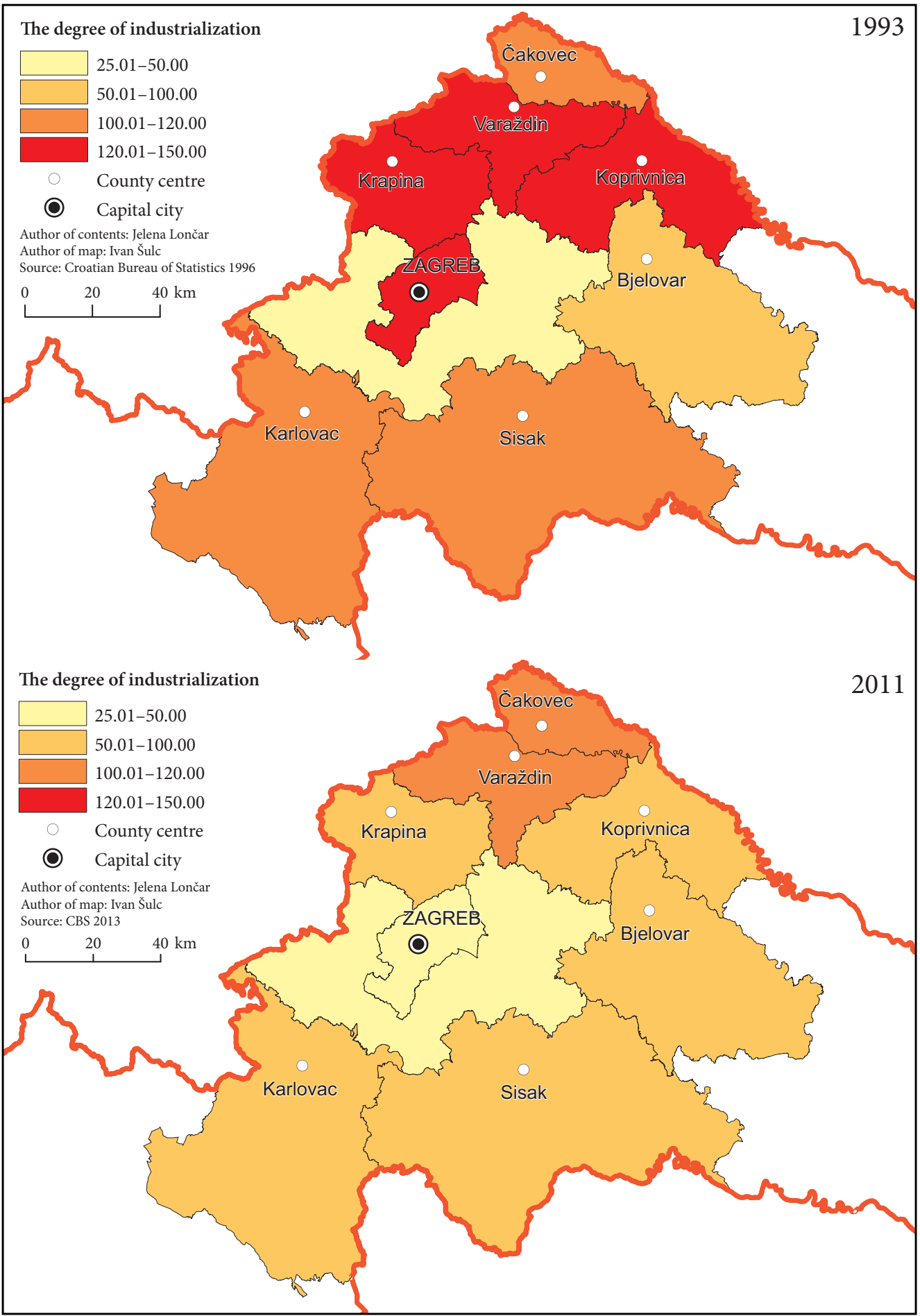

Figure 3: The degree of industrialization by counties of Central Croatia in 1991 and 2011 (Croatian Bureau for Statistics 2001; 2013; calculated by authors). 


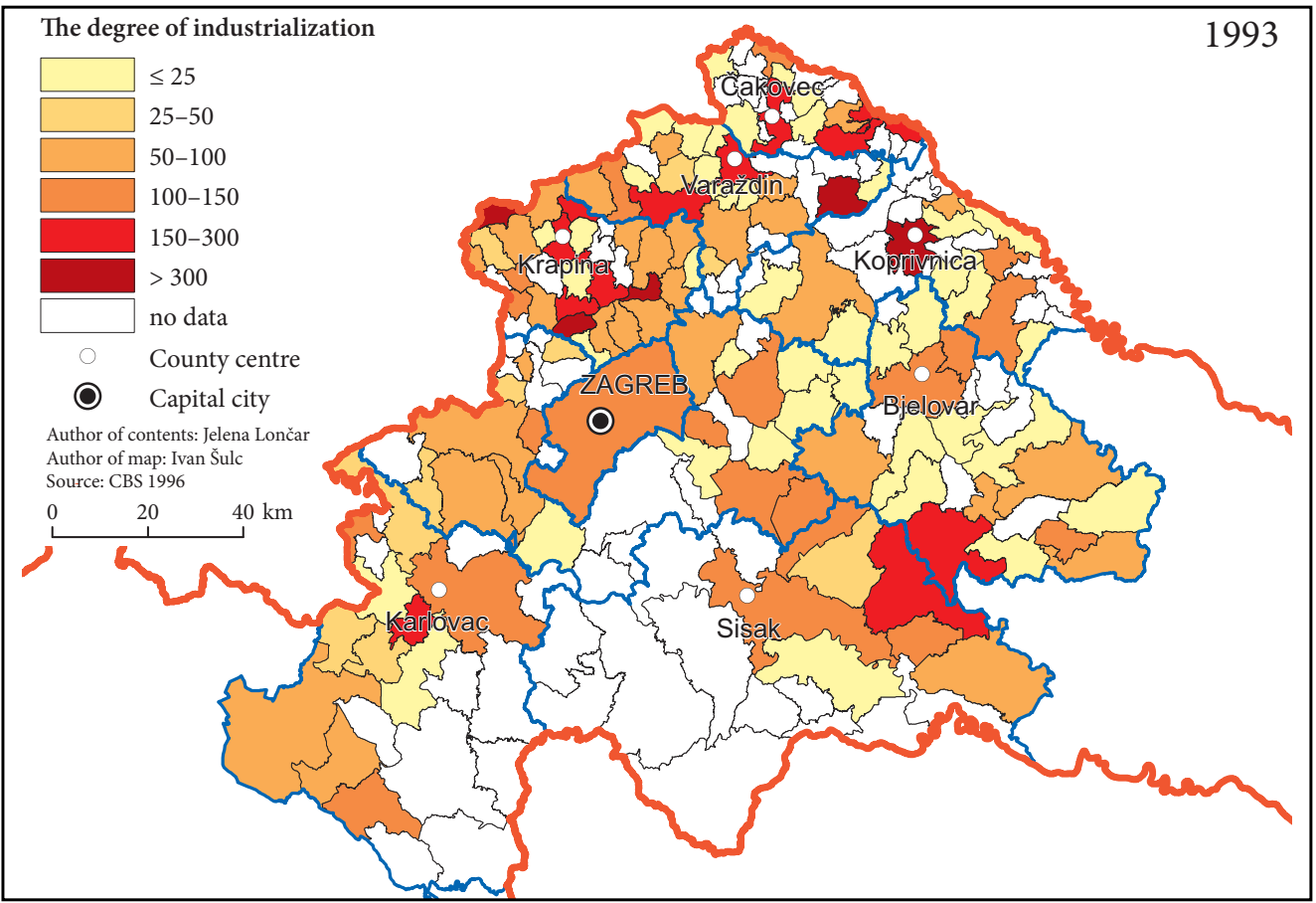

Figure 4: The degree of industrialization by municipalities and cities of central (roatia in 1993 (Croatian Bureau of Statistics, 1996b).

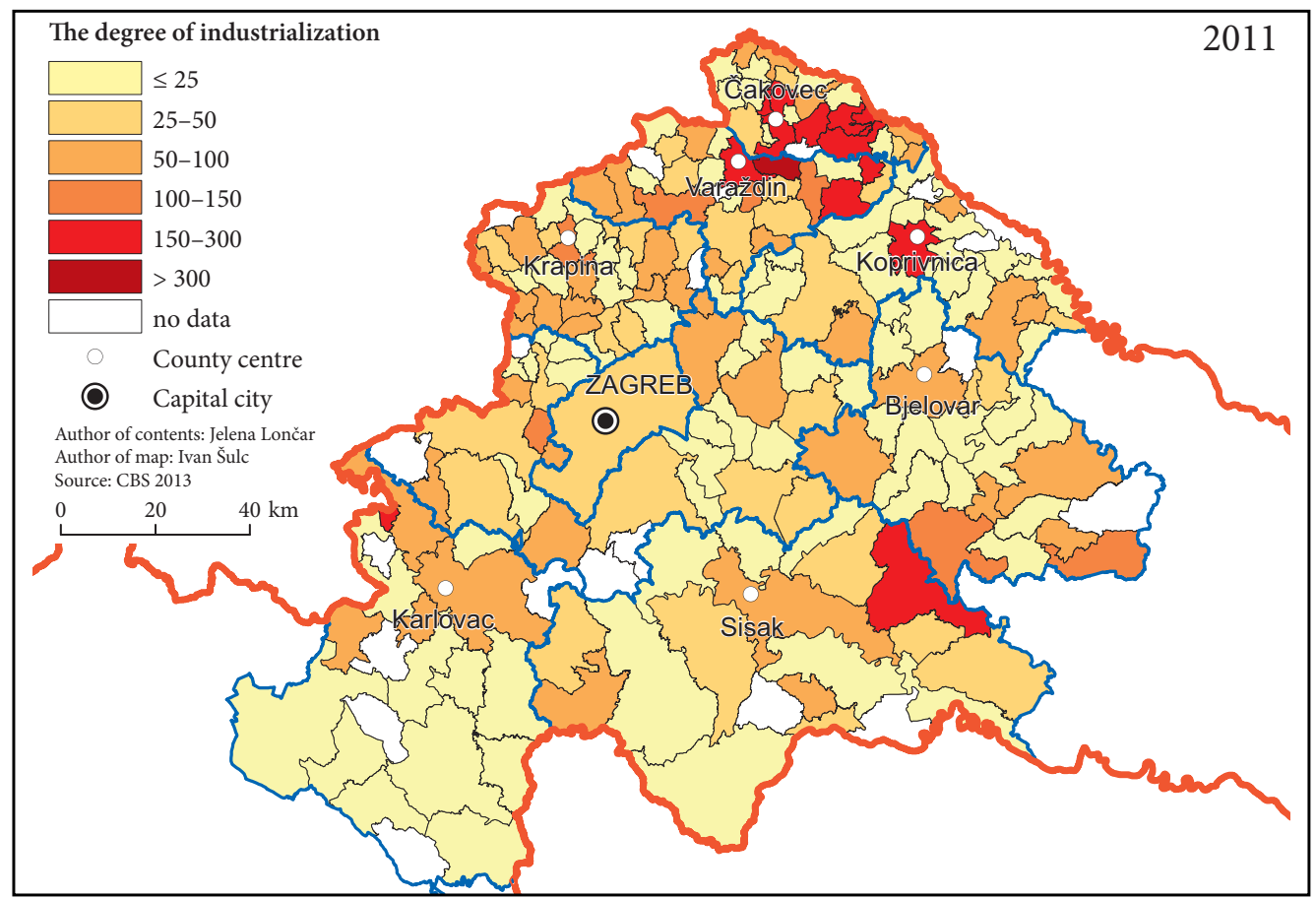

Figure 5: The degree of industrialization by municipalities and cities of central Croatia in 2011. 
the level of the degree of industrialization, certain counties (cities or municipalities) can be classified: if there is more than 150 industrial workers per 1000 residents, we are talking about a highly industrialized area (that in which industry dominates in economical structure and is a factor of transformation), if the number is 100-149, it is medium industrialized, 60-99 - poorly industrialized, less than 60 - the area is at the beginning of the process of industrialization (Feletar and Stiperski 1992).

Degree of industrialization was also calculated and analyzed by municipalities and cities for 1993 and 2011 (Figures 4 and 5), in order to gain a more detailed picture of changes that have happened in industry over the past twenty years. It should be noted that in 1993, because of the war situation, it was not possible to obtain data for many cities and municipalities. It is also important to outline that many industrial manufacturers, in order to survive in the new market, abandoned their traditional production and were forced to extend the range or reorient the production of other products, which lead to a change in the identity of industrial production in some areas. In 2011, the degree of industrialization was lower than in 1993, which is to be expected given that the number of employees in the industry had significantly declined. As for the previous period, data on the number of employees in the industry do not exist and have not been calculated, because in the specified year, there were no workers employed in industry in those municipalities and cities.

Also, it is justified to say that on whole industry as well as the degree of industrialization, domestic and foreign investments has great impact. The accumulation (or lack) of investment activities in selected environments in the consequence of a number of factors where social economic differentiation in a region is reflected in changed location factors and where its advantages or disadvantages also contribute to the occurrence of new social and regional inequalities (Ravbar 2009).

\section{Location quotients as indicators of trend in development of industry in (Central) Croatia}

In order to get the most reliable picture of spatial distribution of industry, supported by specific data, as well as its changes over time, there are quantitative measures for this important indicator. For analyzing the spatial distribution and certain classification of counties in Central Croatia in relation to the distribution of industry, the location quotient was selected. As a basis, it requires two relatively safe and comparable data: the number of employees in the industry (of the county) and the number of employees in relation to a larger spatial unit. This indicator, thus, considers safe elements and can be compared over a longer period of time. What is particularly important, location quotient gives a much more realistic picture of the distribution of industry in space, because it puts its level of development in a relation to a number of residents of the smaller unit. In addition, this indicator also puts a smaller unit in a specific location in relation to average level of development of industry in a larger unit-this average is typically marked with 1000 (Feletar 1984). Also, this indicator allows us to perform a certain classification (typology) of the counties according to relative industrial development. Classification from D. Feletar (1984) is slightly modify and

Table 3: Location quotients by counties of Central Croatia compared to Central Croatia and Croatia in general, 1993 and 2011.

\begin{tabular}{|c|c|c|c|c|c|c|c|c|}
\hline \multirow[b]{2}{*}{ County } & \multicolumn{4}{|c|}{ Central Croatia } & \multicolumn{4}{|c|}{ Republic of Croatia } \\
\hline & 1993 & type & 2011 & type & 1993 & type & 2011 & type \\
\hline Zagreb & 0,41 & b & 0,66 & B & 0,6 & b & 0,71 & c \\
\hline Krapina-Zagorje & 1,33 & B & 1,00 & A & 1,33 & B & 1,33 & $B$ \\
\hline Sisak-Moslavina & 1,09 & A & 1,00 & A & 1,4 & B & 1,00 & $A$ \\
\hline Karlovac & 0,87 & $c$ & 0,83 & $c$ & 1,33 & B & 1,00 & A \\
\hline Varaždin & 1,5 & B & 1,87 & C & 2,0 & C & 2,25 & D \\
\hline Koprivnica-Križevci & 1,4 & B & 1,2 & A & 2,0 & C & 2,00 & $C$ \\
\hline Bjelovar-Bilogora & 0,83 & c & 1,00 & A & 1,0 & A & 1,5 & $B$ \\
\hline Međimurje & 1,0 & A & 1,8 & $C$ & 1,5 & B & 2,5 & D \\
\hline City of Zagreb & 1,1 & A & 0,81 & $c$ & 1,37 & B & 1,00 & $A$ \\
\hline
\end{tabular}

Source: Croatian Bureau of Statistics, 1994b; 2013; calculated by authors. 
therefore, developed as follows: a - counties with undeveloped industry (up to 0,399); b - counties with partially developed industry $(0,400-0,699)$; c - counties with average industrial development $(0,700-0,999)$; A - counties with industry development slightly above average $(1,000-1,300)$; B - counties with medium developed industry $(1,301-1,600)$; $\mathrm{C}$ - counties with industry being their dominant activity $(1,601-2,000)$; $\mathrm{D}$ - counties extremely focused on industry (more than 2,000). Based on this set of criteria, values of the location quotients for all counties of Central Croatia in 1993 and 2011, compared to Central Croatia and Croatia in general were calculated.

Most counties in Central Croatia in 1993 can be categorized as type A and B, i.e. most countries were in the category with industry developed slightly above average (Sisak-Moslavina, Međimurje, City of Zagreb) and counties with medium developed industry (Krapina-Zagorje, Varaždin, Koprivnica-Križevci). Twenty years later, location quotient indicates that type A was dominant, meaning that the industry as an activity in space had »decreased « and been replaced by some other economic activities. Counties where industry was more prominent than in other parts of Central Croatia are Varaždin and Međimurje, with industry being their dominant sector in 2011. This is another indicator that the north-western part of Central Croatia region is an area of larger industrial employment and development. But, from the national viewpoint, it is important for balanced regional development that economic development increases the attractiveness of an entire region and with it improves the quality of life (Ravbar 2004).

\section{Indices of specialization}

Another indicator of the economic structure of an area are indices of specialization of the employees structure that show the development of a smaller economic area in comparison to a larger one (Turčić and Hunjet 2002; Braičić et al. 2009). In this case, it is again industry in counties of Central Croatia compared to industry in Croatia in general.

Table 4: Indices of specialization by counties of Central Croatia in 1990 and 2011.

\begin{tabular}{lll}
\hline County & 1990 & 2011 \\
\hline Zagreb & 0,51 & 1,1 \\
Krapina-Zagorje & 1,68 & 1,65 \\
Sisak-Moslavina & 1,22 & 1,45 \\
Karlovac & 1,31 & 1,2 \\
Varaždin & 1,40 & 2,00 \\
Koprivnica-Križevci & 1,50 & 1,75 \\
Bjelovar-Bilogora & 1,11 & 1,45 \\
Međimurje & 1,35 & 2,3 \\
City of Zagreb & 0,82 & 0,55 \\
\hline
\end{tabular}

Source: Croatian Bureau of Statistics, 1992c; 2012; calculated by authors.

Analysis showed that in 1990 all counties except Zagreb County and the City of Zagreb, were specialized in the field of industry with respect to Croatia as a whole, which is to be expected, given that the industry is the most important activity in Central Croatia when talking about the number of employees. Indices of specialization are, however, relatively small, because the total number of employees in Croatia, which is divided by the number of employees in counties, includes other activities such as tourism (which is especially developed on the coast) which gives a relatively low index of specialization in industry at the level of Central Croatia. In 2011, index of specialization increased in most counties, except in the City of Zagreb, Karlovac and Krapina-Zagorje. A particularly significant increase was recorded in Varaždin and Međimurje County which suggest that the observed counties focused on industry as a leading activity of the central part of Croatia and that it has even greater significance for this area than in 1990.

\section{Conclusion}

Changes that happened in industry in both Central Croatia and Croatia as a whole are a result of deindustrialization of the economy and poor processes of transformation and privatization. Although the number 
of industry employees declined almost everywhere in Central Croatia, great regional differences in terms of changes in the industrial sector have reflected on the importance of industry in spatial structures of certain parts of Central Croatia. Changes referring to the distribution of industry and its volume changed the spatial picture of Central Croatia, which can be seen in the results of calculations applied in this study. These results confirm both hypothesis laid out in Theoretical framework. Judging by the most indicators, the significance of industry as a spatial transformation factor is particularly reduced in southern and eastern parts of Central Croatia. This is partly a consequence of war in the nineties, but also other factors, such as different and less favorable industrial structure based on heavy industry that was created here in the last decades, and which was less adaptable to the new market system. Having analyzed the data, it should be outlined that in order to revive industry and production, Croatia as a whole needs a good industrial policy, i.e. a strategy of industrial development that would serve as a basis for a complete reindustrialization and knowledge and innovation-based industry.

\section{References}

Botrić, V. 2003: Regionalni aspekti nezaposlenosti u Hrvatskoj. Privredna kretanja i ekonomska politika 95. Braičić, Z., Stiperski, Z., Njegač, D. 2009: Utjecaj gospodarske tranzicije i rata na promjene u prostornoj slici zaposlenosti Sisačke regije. Hrvatski geografski glasnik 71-1.

Braičić, Z., Lončar, J. 2011: Unutarregionalni dispariteti u Sisačko-moslavačkoj županiji. Geoadria 16-1.

Braičić, Z., Lončar, J. 2012: Međuzavisnost industrijalizacije i nekih oblika socijalne mobilnosti stanovništva u sisačkom i petrinjskom kraju. Geoadria 17-2.

Feletar, D. 1984: Lokacijski kvocijent i regionalni faktor kao pokazatelji prostorne distribucije i trenda razvoja industrije u SR Hrvatskoj. Radovi 19.

Feletar, D., Stiperski, Z. 1992: Značenje i prostorni razmještaj industrije Hrvatske. Geografski horizont 2.

Feletar, D., Stiperski, Z. 1992: Interdependence of processes of industrialization and changes in spatial distribution and mobility of the population in Croatian Zagorje. Acta Geographica Croatica 27-1.

Feletar, D., Stiperski, Z. 1997: Procesi tranzicije kao faktor promjena broja i strukture stanovništva županijeskih središta u Hrvatskoj. Acta Geographica Croatica 32.

Kalogjera, D. 1993: Privatizacija u stabilizaciji i razvoju hrvatskog gospodarstva. Društvena istraživanja 2-1. Zagreb.

Lokin, B., Mlinarević, M., Živković, M. 2007: Industrijska politika i EU. Ekonomska politika Hrvatske. Opatija. Lorber, L. 1999: The economic transition of Slovenia in the proces of globalization. Geografski zbornik 39.

Magaš, D. 1998: Osnove geografije Hrvatske. Zadar.

Magaš, D. 2013: Geografija Hrvatske. Zadar.

Miljanović, D., Miletić, R., Đorđević, J. 2010: Regional inequality in Serbia as a development problem. Acta geographica Slovenica 50-2. DOI: http://dx.doi.org/10.3986/AGS50204

Obadić, A. 2003: Industrijska politika. Hrvatski gospodarski razvoj. Zagreb.

Ravbar, M. 2004: Regional development in the regional divisions of Slovenia. Acta geographica Slovenica 44-1. DOI: http://dx.doi.org/10.3986/AGS44101

Ravbar, M. 2009: Economic geographical assessment of Investments - A development factor in regional development. Acta geographica Slovenica 49-1. DOI: http://dx.doi.org/10.3986/AGS49105.

Stiperski, Z. 1991: Industrijska područja Hrvatske s polazišta središnjosti odnosno rubnosti. Acta Geographica Croatica 26-1.

Stiperski, Z. 1995: Atraktivnost prostora za razvoj industrije na primjeru Hrvatske. Acta Geographica Croatica 30.

Stiperski, Z. 2007: Promjene u hrvatskoj industriji tijekom tranzicijskog razdoblja. 4. hrvatski geografski kongres. Zagreb.

Teodorović, I., Buturac, G. 2006: Perspektive industrijske proizvodnje u Hrvatskoj i intraindustrijska razmjena. Ekonomski pregled 57-11.

Turčić, I., Hunjet, D. 2002: Neke osnovne strukturne karakteristike po oblicima vlasništva i veličini poduzeća i poslovanje gospodarstva Hrvatske u godini 2000. Ekonomski pregled 53-1/2.

Croatian economy. Croatian chamber of commerce, 2011. Zagreb. Internet: www.hgk.hr (28.4.2013).

Croatian Bureau of Statistics. 1992a: Statistical Yearbook. Zagreb 
Croatian Bureau of Statistics. 1992b: Statistical Reports. Zagreb.

Croatian Bureau of Statistics. 1992c: Employment and salaries. Zagreb.

Croatian Bureau of Statistics. 1993: Statistical Yearbook of Croatian Counties. Zagreb.

Croatian Bureau of Statistics. 1994a: Statistical Yearbook 1995. Zagreb.

Croatian Bureau of Statistics. 1994b: Statistical Reports. Zagreb.

Croatian Bureau of Statistics. 1996a: Industry in 1996. Zagreb.

Croatian Bureau of Statistics. 1996b: Employment and salaries. Documentation 941. Zagreb.

Croatian Bureau of Statistics. 1997: Statistical Yearbook 1998. Zagreb.

Croatian Bureau of Statistics. 2001: Employment and salaries. (www.dzs.hr) (5.4.2013.)

Croatian Bureau of Statistics. 2002: Statistical Yearbook 2003. Zagreb.

Croatian Bureau of Statistics. 2007a: Statistical Yearbook 2008. Zagreb.

Croatian Bureau of Statistics. 2007b: Statistical Reports. Zagreb.

Croatian Bureau of Statistics. 2008a: Statistical Yearbook 2009. Zagreb.

Croatian Bureau of Statistics. 2008b: Statistical Reports. Zagreb.

Croatian Bureau of Statistics. 2011: Review by Counties. (www.dzs.hr) (5.4.2013.)

Croatian Bureau of Statistics. 2012a: Statistical Yearbook. Zagreb

Croatian Bureau of Statistics. 2012b: Statistical Reports. Zagreb.

Croatian Bureau of Statistics. 2013: Employment and salaries. Documentation 1476. Zagreb

Internet 1: www.privredni.hr (28.4.2013). 